\title{
THE CONTENT OF SELENIUM, POLYPHENOLS AND ANTIOXIDATIVE ACTIVITY IN SELECTED MEDICINAL PLANTS FROM POLAND AND WESTERN UKRAINE
}

\author{
ZOFIA SOTEK ${ }^{1 *}$, BOŻENNA BIAŁECKA ${ }^{2}$, BOGUMIŁA PILARCZYK ${ }^{3}$, BARNA KRUZHEL ${ }^{4}$, \\ RADOSŁAW DROZD ${ }^{5}$, RENATA PILARCZYK ${ }^{6}$, AGNIESZKA TOMZA-MARCINIAK ${ }^{3}$, \\ HALYNA LYSAK ${ }^{4}$, MAŁGORZATA BĄKOWSKA ${ }^{3}$ and STAKH VOVK ${ }^{7}$
}

${ }^{1}$ Department of Botany and Nature Conservation, Faculty of Biology, University of Szczecin, Felczaka 3c, 71-412 Szczecin, Poland

${ }^{2}$ Molecular Biology and Biotechnology Center, Environmental Research Laboratory, Faculty of Biology, University of Szczecin, Małkocin 37, 73-110 Stargard, Poland

${ }^{3}$ Department of Animal Reproduction Biotechnology and Environmental Hygiene,

West Pomeranian University of Technology in Szczecin, Janickiego 29, 71-270 Szczecin, Poland

${ }^{4}$ Department of Biotechnology and Animal Science, Lviv National Agrarian University, Lviv-Dubljany, 80381, Ukraine

${ }^{5}$ Department of Immunology, Microbiology and Physiological Chemistry, West Pomeranian University of Technology in Szczecin, Judyma 24, 71-466 Szczecin, Poland

${ }^{6}$ Laboratory of Biostatistics, West Pomeranian University of Technology in Szczecin, Janickiego 29, 71-270 Szczecin, Poland

${ }^{7}$ Institute of Agriculture of Carpathian, National Academy of Agrarian Sciences of Ukraine, Obroshyno, Pustomyty, Lviv, 81115, Ukraine

\begin{abstract}
The three aims of the study were to: 1) evaluate the content of selenium and polyphenols, and to assess the reductive potential (FRAP test) and ability to deactivate $\mathrm{ABTS}^{++}$cation radicals in $C$. officinalis, $H$. perforatum, M. x piperita and S. marianum from Poland and Ukraine; 2) define the diversification in concentrations of selenium and polyphenols and in levels of ABTS activity and FRAP reductive potential within the examined species in relation to their location; and 3) evaluate the inter-dependencies between selenium, total polyphenol concentration, ABTS and FRAP activity, in the examined plants. We observed differences in the content of total polyphenols and antioxidative activity between the herb species and the location. Most selenium was found in M. x piperita and S. marianum from western Ukraine, with Polish H. perforatum from Pomerania and M. x piperita from Podlasie representing the highest TP content and antioxidative potential. A clear and significant relationship between the content of Se and antioxidative activity (ABTS and FRAP), and also between total polyphenols and antioxidative activity was noted only in $H$. perforatum. In C. officinalis a significant relationship was noted between Se and both total polyphenols and antioxidative potential. In M. x piperita a significant dependency was found between total polyphenols and antioxidative potential. The results of our research indicate a different role of selenium as an antioxidant in $H$. perforatum and $C$. officinalis, as well as polyphenols in $H$. perforatum and $M$. x piperita in dependence on the harvesting regions.
\end{abstract}

Keywords: herbs, selenium, ABTS $^{++}$, FRAP, polyphenols

It was established that living systems generate free radicals as a result of normal biochemical reactions. An increase in free radical formation can be caused by factors such as UV radiation, smoking, air pollutants etc. Uncontrolled free radical production is considered to play a causative role in cellular damage, related to damage to DNA, lipids and proteins, and thus to pathological conditions including cardiovascular defects, cancer, inflammation, liver and kidney failure and different neurodegenerative and age-re-

\footnotetext{
* Corresponding author: e-mail: sotek@univ.szczecin.pl
} 
lated disorders (1-3). The human body is naturally equipped with an endogenic enzymatic defense system that includes superoxide dismutase, catalase, glutathione peroxidase, for free radical neutralization, supported by minerals such as selenium (Se), vitamins $\mathrm{C}$ and $\mathrm{E}$, carotenoids (eg. $\beta$-carotene, lycopene, lutein), and plant origin polyphenols (flavonoids, phenolic acids, tannins, coumarins and others).

For humans, selenium is considered both a vital and a toxic ultra-element in relation to its concentration. According to the World Health Organization (WHO), the basic demand to prevent pathologically relevant and clinically detectable signs of functional abnormalities is $20 \mathrm{mg} \mathrm{Se} /$ day (4). A consumption of $40-55 \mathrm{mg} \mathrm{Se} /$ day was described as proper, with a toxic effect at $350 \mathrm{mg}$ Se or higher per day. A prolonged intake of inorganic selenium compounds in concentrations higher than 5 ppm may cause hepatotoxic and teratogenic effects (5). A variety of plants, including groups that may represent medicinal properties like cereals, grains and vegetables, are a valuable source of selenium for humans.

The particular role of Se as a nutritional trace element for humans and animals is related to its presence in at least 25 proteins and seleniumdependent enzymatic systems. All mammalian selenoproteins contain Se bound in the selenocysteine amino acid (5). About half of the described selenoproteins play an antioxidative role and protect cells from free radical damage. An increase in antioxidative stress and changes in redox signaling are considered reasons behind diseases caused by a selenium deficiency, including Keshan disease, muscular dystrophy, Kashin-Beck disease, cancer, immune system deficiencies and a decline in thyroid function (5). Between the selenium-containing enzymes, a particularly important role is played by glutathione peroxidases, whose role it is to reduce lipid peroxidation by decreasing the accumulation of peroxides and hydroperoxides.

It has been shown that plants characterized by their medicinal value are a rich source of polyphenol compounds, and some of them also selenium $(6,7)$. The well-known antioxidative activity of most polyphenols results from different mechanisms of molecular activity, such as the capacity to create stable phenoxyl radicals via expanded electron delocalization or hydrogen bonding or to chelate metal ions (6, 8). Species like Calendula officinalis L., Hypericum perforatum L., Mentha x piperita L. and Silybum marianum (L.) Gaertn. belong to a group of herbs traditionally used for the treatment and prevention of liver and gallbladder diseases. C. officinalis grows in the wild or in home gardens in Europe and
North America (9). The presence of several secondary bioactive metabolites such as flavonoids and triterpenoids were found in its flowers $(10,11) . H$. perforatum is a native species for Europe and Asia, and naturalized in North America; it has a diuretic activity and contains some active substances such as hyperforin and hypericin, as well as flavonoids and tannins (12). M. x piperita is a natural hybrid of $M$. aquatica $\mathrm{L}$. and M. spicata $\mathrm{L}$. and is a native plant in Europe, naturalized in North America and has grown in many regions of the world. Its leaves and essential oils are considered to be the most valuable curative substrates of M. x piperita and are commonly used as a folk remedy or in complementary and alternative medical therapy for spasms of the bile duct and gallbladder problems. M. x piperita produces different metabolites as terpenes (menthol, menthone), tannins, flavonoids and phenolic acids (13). S. marianum seeds and their extracts are used against some viral infections and liver cirrhosis, and in the treatment of jaundice. They are also used to protect the liver from toxins, caused for example by mushroom poisoning, alcohol overdosing or insect stings (14). S. marianum contains sylimarin - an active flavonoid complex, in which silybin is the main component (15).

Herbs used in phytotherapy are mostly applied as water infusions, a traditional method of polyphenol extraction performed at 20 to $50^{\circ} \mathrm{C}$, where a temperature in this range enhances the efficiency of extraction. This is the result of the increased permeability of the cell walls, and solubility and diffusion factors of extracted compounds. A temperature higher than $50^{\circ} \mathrm{C}$ is inadvisable as it causes polyphenol degradation (16).

Regarding the above aspects, we used water extracts from examined plants in our analysis.

The three aims of the study were to: 1) evaluate the content of selenium and polyphenols, assess the reductive potential (FRAP test) and ability to deactivate $\mathrm{ABTS}^{++}$cation radicals in the selected herb species from Poland and Ukraine; 2) define the diversification in concentrations of selenium and polyphenols and in levels of ABTS activity and FRAP reductive potential within the examined species in relation to their location; and 3) evaluate the inter-dependencies between selenium, total polyphenol concentration, ABTS and FRAP activity, in the examined plants.

\section{MATERIALS AND METHODS}

\section{Plant material}

Plant material from four types of herbs; Calendula officinalis - inflorescences, Hypericum perforatum - herb, Mentha x piperita - herb and 
Silybum marianum - seeds, were examined in the study. The plants were collected in two regions of northern Poland (Pomerania - Połczyn Zdrój and Podlasie - Koryciny), and in western Ukraine (Lviv region - Zabłotce), while S. marianum was collected only in Podlasie and Ukraine. The material was collected during 2014 and 2015 from organic farms, home gardens and unfertilized wild soils. The material was dried in natural conditions.

\section{Selected climatic factors}

The test samples were collected from areas classified in the Koppen-Geiger system as Dfb climate: temperate continental climate/humid continental climate (17).

In Połczyn Zdrój (Pomerania), annual precipitation is rather high, reaching $650 \mathrm{~mm}$. The highest mean rainfalls are observed in July at $82 \mathrm{~mm}$ and the lowest in February at $30 \mathrm{~mm}$. Mean annual temperature is $7.7^{\circ} \mathrm{C}$; July is the warmest month (mean temperature $17.7^{\circ} \mathrm{C}$ ) and January the coldest (mean temperature $-3.4^{\circ} \mathrm{C}$ ). During the summer months (June-July) the minimal temperature is $11.2^{\circ} \mathrm{C}$ and the maximal is $22 \cdot 1^{\circ} \mathrm{C}(18)$.

In Koryciny (Podlasie), precipitation over the year oscillates around $560 \mathrm{~mm}$, with the highest mean rainfalls noted in July, $75 \mathrm{~mm}$, and the lowest in February, $28 \mathrm{~mm}$. Mean annual temperature is $6.9^{\circ} \mathrm{C}$. The warmest month is July with a mean temperature of $18.0^{\circ} \mathrm{C}$, with the lowest mean temperature noted in December at $-2.3^{\circ} \mathrm{C}$. During the summer months, the minimal temperature is $10.9^{\circ} \mathrm{C}$ and the maximal is $23.4^{\circ} \mathrm{C}(18)$.

Due to a lack of climatic data regarding Zabłotce (Lviv region), we decided to use the data from the closest available location in Brody. Mean annual precipitation in that area reaches $602 \mathrm{~mm}$, the highest mean rainfalls are typical in July at $87 \mathrm{~mm}$ and the lowest in the first three months of the year, January $-31 \mathrm{~mm}$, February and March - $30 \mathrm{~mm}$. Mean annual temperature in $7.6^{\circ} \mathrm{C}$. The warmest month is July at 18.5 , and the coldest is January at $4.5^{\circ} \mathrm{C}$. During the summer months, the minimal temperature is $11.9^{\circ} \mathrm{C}$ and the maximal is $23.8^{\circ} \mathrm{C}(18)$.

\section{Selenium content}

The concentration of selenium in the herbs was determined using the Watkinson spectrofluorometric method (19), as modified by Grzebuła and Witkowski (20). The plant tissues were digested in $\mathrm{HNO}_{3}$ at $230^{\circ} \mathrm{C}$ for $180 \mathrm{~min}$, then in $\mathrm{HClO}_{4}$ at $310^{\circ} \mathrm{C}$ for $20 \mathrm{~min}$. The samples were then hydrolyzed with $9 \% \mathrm{HCl}$. Selenium was derivatized with 2,3-diaminonaphthalene (SigmaAldrich) and the complex was extracted into cyclo- hexane. Se concentration was measured fluorometrically using a Shimadzu RF-5001 PC spectrophotofluorometer. The excitation wavelength was $376 \mathrm{~nm}$, and fluorescence emission wavelength was $518 \mathrm{~nm}$.

The accuracy of the method for the tested herbs was verified using BCR-402 White clover Certified Reference Material. The level of recovery was as $89 \%$ of the reference value.

\section{Sample preparation}

$100 \mathrm{mg}$ of each type of dried herb material was powdered with a mortar and pestle, transferred to a $10 \mathrm{~mL}$ plastic tube, and filled to $5 \mathrm{~mL}$ with deionized water heated to $50^{\circ} \mathrm{C}$. The suspension was then stirred vigorously and left for $45 \mathrm{~min}$ in the shade. Then the tubes were centrifuged at $15000 \mathrm{rpm}$ for 10 $\min$ at $4^{\circ} \mathrm{C}$. The supernatant obtained in this procedure was used within $24 \mathrm{~h}$ for total polyphenol content, free radical ABTS scavenging ability and ferric reducing antioxidant power (FRAP) assays.

\section{Total polyphenol content assay}

Total polyphenol content of the extracts was determined using the Folin-Ciocalteu method, modified to a microplate reader format (21). The total amount of polyphenolic compounds was expressed as $\mathrm{mg}$ of tannic acid equivalent, per $100 \mathrm{~g}$ of the dry mass of sample (mg TAE/100 g DW).

\section{Free radical ABTS scavenging ability assay}

Free radical scavenging activity of the water extracts was determined by a solution of ABTS cation radical discoloration assay, according to (22). The assays were conducted with a microplate reader. In brief, $10 \mu \mathrm{L}$ of sample was added to $300 \mu \mathrm{L}$ of ABTS working reagent, diluted to $0.7 \pm 0.02$ of the absorbance at $734 \mathrm{~nm}$. Next, the initial absorbance was read immediately, while the final absorbance was measured after 6 min. Ascorbic acid was used as a standard for calibration of the method. The percent of ABTS radical inhibition was calculated according to formula (1).

$$
\% \text { inhibition }=\left[\mathrm{A}_{0}-\left(\mathrm{A}_{\mathrm{f}}-\mathrm{B}\right)\right] / \mathrm{A}_{0} \times 100
$$

where $A_{0}$ is the absorbance of the control at $t=0$ min; $A_{f}$ absorbance of the sample after 6 min; $B$ absorbance of a blank sample.

The results were expressed in $\mu \mathrm{M}$ of ascorbic acid equivalent, per $100 \mathrm{~g}$ of the dry mass of sample ( $\mu \mathrm{M}$ AAE/100 g DW).

\section{Ferric Reducing Antioxidant Power (FRAP) assay}

FRAP method modified to a microplate reader format (23) was used in the antioxidant potential 
assay. In brief, FRAP working reagent was prepared by mixing an acetate buffer $(300 \mu \mathrm{M}, \mathrm{pH} 3.6)$ with $10 \mathrm{mM}$ TPTZ in $40 \mathrm{mM} \mathrm{HCl}$ solution, and $20 \mathrm{mM}$ $\mathrm{FeCl}_{3}$ at $10: 1: 1(\mathrm{v} / \mathrm{v} / \mathrm{v})$ ratio. Next, $10 \mu \mathrm{L}$ of sample solutions were added to $300 \mu \mathrm{L}$ of working reagent, preheated to $37^{\circ} \mathrm{C}$. The absorbance was measured at $593 \mathrm{~nm}$ after $6 \mathrm{~min}$. A standard curve was prepared using different concentrations of $\mathrm{FeCl}_{2}$ ranging from 1 to $0.1 \mathrm{mM}$. The antioxidant status was expressed as $\mu \mathrm{mol}$ of $\mathrm{Fe}^{2+}$ equivalent, per $100 \mathrm{~g}$ of the dry mass of sample ( $\mu \mathrm{M} \mathrm{FeE} / 100 \mathrm{~g}$ DW).

\section{Statistical analysis}

The results were analyzed statistically with STATISTICA 12.5 PL software (StatSoft Inc., Tulsa, OK, USA). Shapiro-Wilk tests were used to evaluate the distribution of variables. In the case of a lack of normal distribution, the decimal logarithms of the variables were calculated for further statistical analyses. One-way ANOVA was performed and the significance of differences between the mean values of the examined species and the different regions of collection were calculated using a parametric Tukey

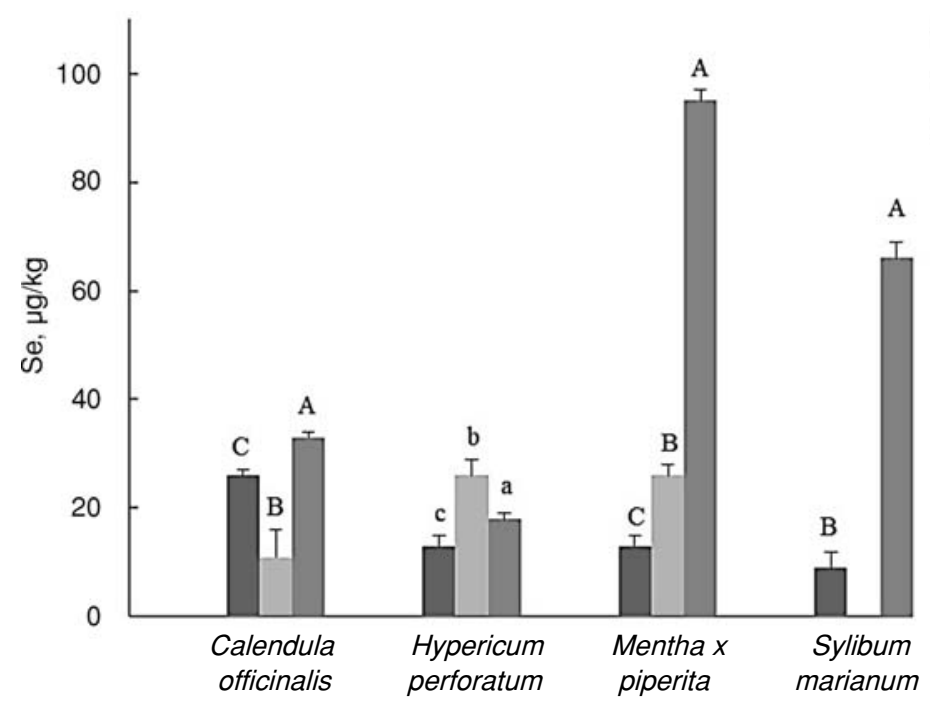

\section{- Podlasie \\ a Pomerania \\ घUkraine}

A

Figure 1. The concentration of selenium (Se) in herbs from Poland: Podlasie, Pomerania and Ukraine. Vertical bars indicate \pm SEM. Different letters indicate statistically significant differences at $\mathrm{p} \leq 0.01$ (capital letters) and $\mathrm{p} \leq 0.05$ (small letters) within a species

Table 1. The mean of total polyphenol content (TP), antioxidant potential (ABTS and FRAP tests) and selenium (Se) in herb samples from selected populations in Poland and western Ukraine.

\begin{tabular}{|c|c|c|c|c|c|}
\hline $\begin{array}{c}\text { Plant species/ } \\
\text { Family }\end{array}$ & $\begin{array}{c}\text { Plant } \\
\text { part }\end{array}$ & $\begin{array}{c}\text { Total polyphenols } \\
(\text { mg TAE/100 g } \\
\text { DW) } \pm \text { SEM }\end{array}$ & $\begin{array}{c}\text { ABTS } \\
(\mu \mathrm{M} \text { AAE/100 g } \\
\text { DW) } \pm \text { SEM }\end{array}$ & $\begin{array}{c}\text { FRAP } \\
(\mu M \text { FeE/100 g } \\
\text { DW) } \pm \text { SEM }\end{array}$ & $\begin{array}{c}\text { Se } \\
(\mu \mathrm{g} / \mathrm{kg} \text { DW) } \\
\pm \text { SEM }\end{array}$ \\
\hline $\begin{array}{c}\text { Calendula } \\
\text { officinalis/ } \\
\text { Asteraceae }\end{array}$ & Flowers & $14.26 \pm 0.51^{\mathrm{a}}$ & $16.44 \pm 1.52^{\mathrm{a}}$ & $36.78 \pm 2.85^{\mathrm{A}}$ & $23.40 \pm 2.45^{\mathrm{a}}$ \\
\hline $\begin{array}{c}\text { Hypericum } \\
\text { perforatum/ } \\
\text { Hypericaceae }\end{array}$ & Herb & $36.95 \pm 6.87^{\mathrm{b}}$ & $64.70 \pm 5.32^{\mathrm{b}}$ & $211.7 \pm 42.32^{\mathrm{B}}$ & $29.73 \pm 10.84^{\mathrm{a}}$ \\
\hline $\begin{array}{c}\text { Menthax } \\
\text { piperita/ } \\
\text { Lamiaceae }\end{array}$ & Herb & $31.72 \pm 4.26^{\mathrm{b}}$ & $43.36 \pm 8.42^{\mathrm{c}}$ & $192.23 \pm 12.21^{\mathrm{B}}$ & $44.79 \pm 9.50^{\mathrm{a}}$ \\
\hline $\begin{array}{c}\text { Sylibum } \\
\text { marianum/ } \\
\text { Asteraceae }\end{array}$ & Seeds & $3.07 \pm 0.71^{\mathrm{a}}$ & $1.98 \pm 0.19^{\mathrm{a}}$ & $4.52 \pm 0.56^{\mathrm{A}}$ & $37.90 \pm 9.60^{\mathrm{a}}$ \\
\hline
\end{tabular}

Values are the mean of 15 (Sylibum marianum - 10) measurements \pm SEM (the standard error of measurement). The different capital letters indicate statistically significant differences at $\mathrm{p} \leq 0.01$. The different small letters indicate statistically significant differences at $\mathrm{p} \leq 0.05$ 


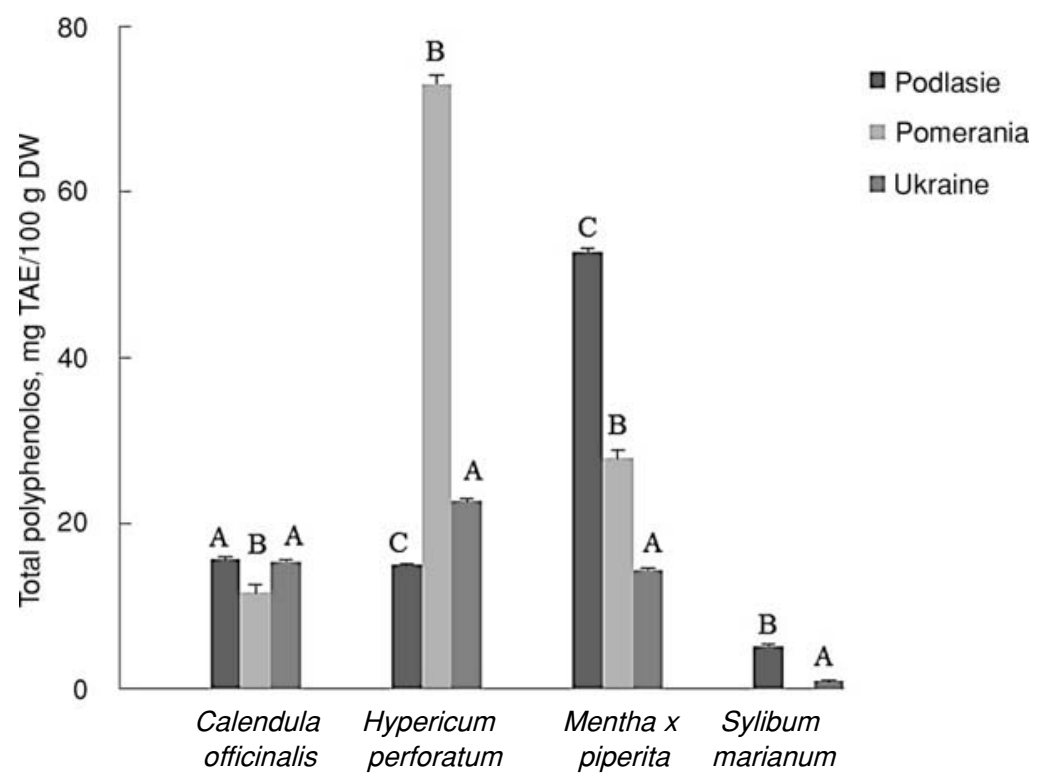

Figure 2. The content of total polyphenols in herbs from Poland: Podlasie, Pomerania and Ukraine. Vertical bars indicate \pm SEM. Different letters indicate statistically significant differences at $\mathrm{p} \leq 0.01$ within a species

test. Differences were considered significant at $\mathrm{p} \leq 0.05$ using Pearson correlation coefficient. Statistical significance of the correlation coefficients was tested at $\mathrm{p} \leq 0.01$.

\section{RESULTS}

\section{Selenium content}

The examined species did not differ significantly in mean concentration of selenium (Table 1). The content of selenium ranged from 9 to $95 \mu \mathrm{g} / \mathrm{kg}$ DW (Fig. 1). For all the plants had significant differences in the levels of selenium with respect to the region of sample collection. The highest Se content was found in M. x piperita from Ukraine (95.0 \pm 2.0 $\mu \mathrm{g} / \mathrm{kg} \mathrm{DW}$ ) and the lowest level of Se was observed in $S$. marianum from Podlasie $(9.00 \pm 3.0 \mu \mathrm{g} / \mathrm{kg}$ DW. In all the examined species, except $H$. perforatum, significantly more selenium $(\mathrm{p} \leq 0.01)$ was found in the plants from Ukraine.

\section{Total polyphenols}

The mean polyphenol content was significantly ( $\mathrm{p} \leq 0.05$ ) higher in $H$. perforatum and $M . x$ piperita in comparison to $C$. officinalis and $S$. marianum (Table 1). Total polyphenol content in the plants from the different regions ranged from 0.95 to $73.00 \mathrm{mg}$ TAE/100 g DW (Fig. 2). All the analyzed species (excluding $C$. officinalis) significantly dif- fered in total polyphenol content according to the place of sample origin. The highest level of polyphenols was found in $H$. perforatum from Pomerania $(73.00 \pm 0.10 \mathrm{mg}$ TAE$/ 100 \mathrm{~g} \mathrm{DW})$, and the least polyphenols were observed in $S$. marianum from Ukraine $(0.95 \pm 0.05 \mathrm{mg}$ TAE/100 g DW).

\section{ABTS activity}

In the analyzed plants, the mean ABTS values were significantly $(\mathrm{p} \leq 0.05)$ higher in $H$. perforatum and M. x piperita in comparison to $C$. officinalis and S. marianum; simultaneously, ABTS activity in $H$. perforatum was significantly $(\mathrm{p} \leq 0.05)$ higher than in $M$. x piperita (Table 1). The potential to remove $\mathrm{ABTS}^{+}$cation radicals in plants from different regions ranged from 1.41 to $88.42 \mu \mathrm{M}$ AAE/100 g DW (Fig. 3). The highest activity was noted in $H$. perforatum from Pomerania $(88.42 \pm 4.60 \mu \mathrm{M}$ AAE/100 g DW) and in $M$. x piperita from Podlasie $(86.90 \pm 11.39 \mu \mathrm{M}$ AAE/100 g DW), and the lowest in $S$. marianum from Podlasie $(1.41 \pm 0.17 \mu \mathrm{M}$ AAE/100 g DW).

\section{FRAP activity}

In the analyzed plants, the mean FRAP values were significantly ( $\mathrm{p} \leq 0.05$ ) higher in $H$. perforatum and M. x piperita in comparison to C. officinalis and $S$. marianum (Table 1). The FRAP activity in plants from different regions ranged from 2.84 to 
434.01 $\mu \mathrm{M} \mathrm{FeE/100} \mathrm{g} \mathrm{DW} \mathrm{(Fig.} \mathrm{4).} \mathrm{In} \mathrm{all} \mathrm{the} \mathrm{spe-}$ cies, except $C$. officinalis, a significant difference in FRAP activity was noted between the different regions of plant collection. The highest activity was found in $H$. perforatum from Pomerania (434.01 \pm $3.18 \mu \mathrm{M} \mathrm{FeE} / 100 \mathrm{~g} \mathrm{DW}$ ), and the lowest in $S$. marianum from Ukraine $(2.84 \pm 0.06 \mu \mathrm{M} \mathrm{FeE} / 100 \mathrm{~g}$ DW).

Correlations between polyphenol, selenium and ABTS and FRAP activity

An analysis of the Pearson correlation (R) was used to explain the relationship between total polyphenol and selenium content and antioxidative activity measured with ABTS and FRAP methods for all the analyzed plants in each of the regions (Table 2). In H. perforatum and M. x piperita, a very high and significant correlation was noted between the total polyphenol content and ABTS $(\mathrm{R}=0.901$ and $\mathrm{R}=0.939$ respectively, $\mathrm{p} \leq 0.001)$ and FRAP activity $(\mathrm{R}=0.998$ and $\mathrm{R}=0.986$ respectively, $\mathrm{p} \leq 0.01)$. A very high and significant correlation between selenium content and ABTS and FRAP antioxidative potential was confirmed in $C$. officinalis $(\mathrm{R}=0.824$ and $\mathrm{R}=0.977$ respectively, $\mathrm{p} \leq 0.001)$ and $H$. perforatum $(\mathrm{R}=0.892$ and 0.832 respectively, $\mathrm{p} \leq 0.01)$. A very high and significant correlation between selenium and total polyphenol content $(\mathrm{R}=0.884, \mathrm{p} \leq 0.001)$ was noted in $C$. officinalis.

Table 2. Pearson correlation ( $\mathrm{R}$ - coefficient) between selenium (Se), total polyphenols (TP), content and antioxidant assays (ABTS and FRAP).

\begin{tabular}{|c|c|c|c|c|}
\hline Parameter & Calendula officinalis & Hypericum perforatum & Mentha x piperita & Sylibum marianum \\
\hline Se \& ABTS & $0.824^{* *}$ & $0.892^{*}$ & $\mathrm{~ns}$ & $\mathrm{~ns}$ \\
\hline Se \& FRAP & $0.977^{* *}$ & $0.832^{*}$ & $\mathrm{~ns}$ & $\mathrm{~ns}$ \\
\hline Se \& TP & $0.884^{* *}$ & $\mathrm{~ns}$ & $\mathrm{~ns}$ & $\mathrm{~ns}$ \\
\hline TP \& ABTS & $\mathrm{ns}$ & $0.901^{* *}$ & $0.939^{* *}$ & $\mathrm{~ns}$ \\
\hline TP \& FRAP & $\mathrm{ns}$ & $0.998^{*}$ & $0.986^{*}$ & $\mathrm{~ns}$ \\
\hline
\end{tabular}

Significance level: $* * \mathrm{p} \leq 0.001, * \mathrm{p} \leq 0.01$, ns - no significant

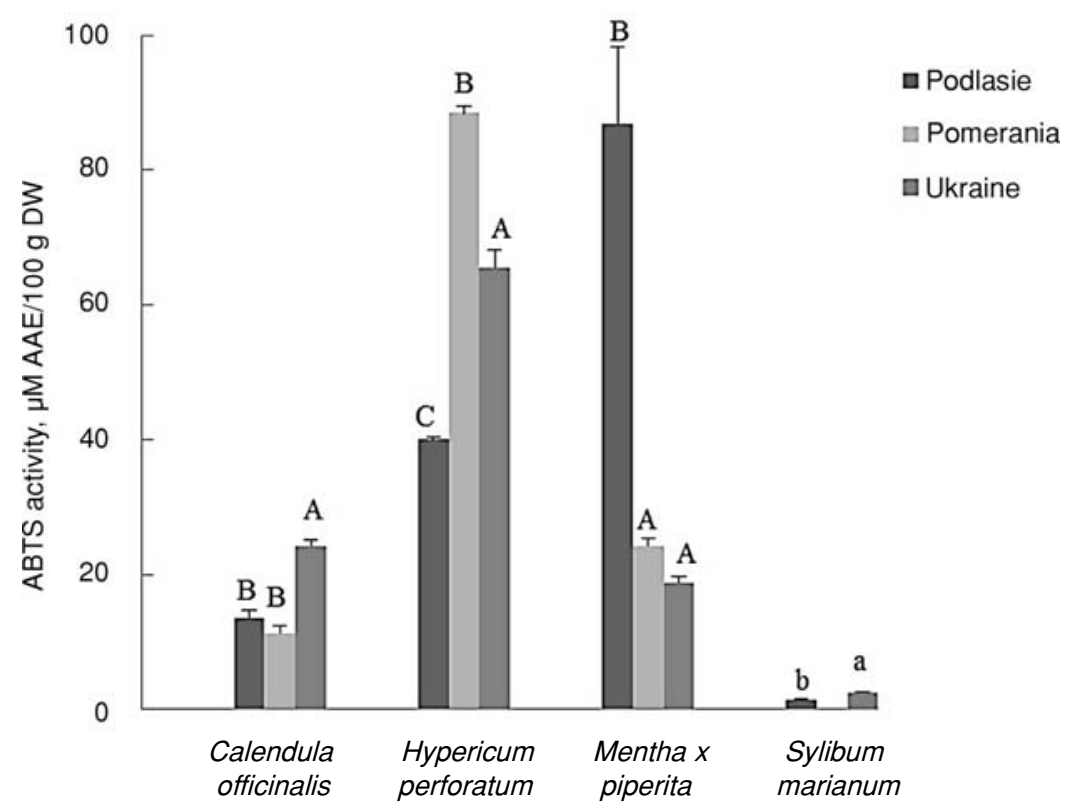

Figure 3. The ABTS activity in herbs from Poland: Podlasie, Pomerania and Ukraine. Vertical bars indicate \pm SEM. Different letters indicate statistically significant differences at $\mathrm{p} \leq 0.01$ (capital letters) and $\mathrm{p} \leq 0.05$ (small letters) within a species 


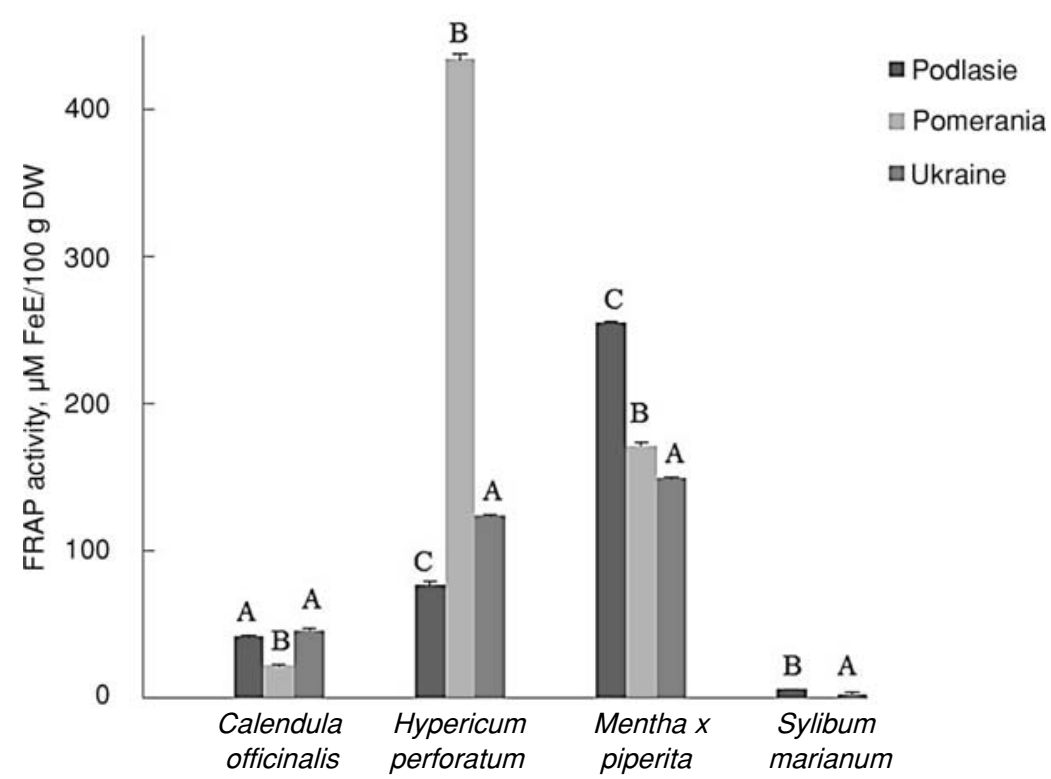

Figure 4. The FRAP activity in herbs from Poland: Podlasie, Pomerania and Ukraine. Vertical bars indicate \pm SEM. Different letters indicate statistically significant differences at $\mathrm{p} \leq 0.01$ within a species

\section{DISCUSSION}

Regarding the growing interest in medicinal plants as a potential group of supportive drugs, determination of factors like the content of selenium and polyphenols and antioxidative potential is a very important and live issue.

Based on the results we have obtained, it may be noticed that the concentration of Se in the analyzed medical plants from Podlasie, Pomerania and Western Ukraine was diverse, ranging from 9.00 to $95.00 \mathrm{mg} / \mathrm{kg} \mathrm{DW}$ (Fig. 1). Among the examined species, mean selenium content did not exceed $45 \mu \mathrm{g} / \mathrm{kg}$ DW (Table 1). Similar results were reported in the study by Antal et al. (24), where in $68 \%$ of the examined medicinal plants in western Romania, the content of Se was lower than $50 \mu \mathrm{g} / \mathrm{kg}$ DW. However, a comparison of our data (Fig. 1, Table 1) with the levels of Se in cereals, vegetables and fruits in Europe $(2-880 \mu \mathrm{g} / \mathrm{kg})(25)$ allows us to notice that the level of this mineral in the medicinal plant samples from the three selected regions we examined was relatively low.

The content of selenium in herbs is related to the species of plant and depends mostly on the abundance of this element in the soil, its chemical form, soil $\mathrm{pH}$, the activity of soil microflora and climatic conditions. Selenates (VI) are the best absorbed form of selenium, as between the other selenium forms (selenites, elementary Se, selenides), selenates (VI) are the easiest to pass from the soil to soil solutions (26). Selenates are absorbed in an active transport using the sulfate transporter localized in cellular membranes of root cells. Plants convert absorbed selenates mostly into selenomethionine and incorporate it into their cellular proteins instead of methionine (27). Between the climatic factors, an important effect on Se accumulation in plants is caused by rainfall and temperature. Large rainfall can contribute to a greater reduction of selenates to other less available forms of selenium in the soil (28). On the other hand, low temperatures hinder selenium intake by plants (29). Based on our results we observed that the selected herbs from Ukraine (except $H$. perforatum) contained significantly more selenium, in some cases even seven times more $(M$. $\mathrm{x}$ piperita and $S$. marianum), in comparison to the samples from Poland (Fig. 1). It does not seem that temperature had an influence on this situation, as for many years the temperature had not differed significantly between the locations where the herbs were collected. However, it may indicate either a higher abundance of selenium in the superficial layers of soil where the plants from Ukraine grew or a higher content of selenates (VI) in the soil. According to the map presenting the selenium abundance of soils in Europe, in the surroundings of Zabłotce (Ukraine), the content of Se ranged from 0.357 to $0.492 \mu \mathrm{g} / \mathrm{kg}$ 
(30). Soil abundance of selenium is indirectly testified by studies on Se content in animals, where those from western Ukraine show optimal levels of this bioelement while at the same time Se levels in Poland are visibly lower (31). The concentration of selenium in the soils of Pomerania and Podlasie (surroundings of Koryciny) is low, ranging from 0.035 to $0.332 \mu \mathrm{g} / \mathrm{kg}$ (32) and from 0.102 to $0.245 \mu \mathrm{g} / \mathrm{kg}$ (30), respectively. Połczyn Zdrój, located in the central part of Pomerania, is characterized by a high annual rainfall $(649 \mathrm{~mm})$ in contrast to the other locations of herb collection. Intensive rainfalls may lead to leaching of the easily soluble selenium compounds from the soil. The low content of selenium in the soils of Pomerania and Podlasie reflect in its low content in the tested herb samples collected in these regions (Fig. 1).

The concentration of Se in the aerial parts of $H$. perforatum was significantly less diverse in the research material from Poland and Ukraine (13-26 $\mu \mathrm{g} / \mathrm{kg}$ DW) (Fig. 1) in comparison to material collected in a study in western Romania $(3-177 \mu \mathrm{g} / \mathrm{kg}$ DW) (24).

The antioxidative activity that protects plant cells from free radicals is one of many interesting features of plant-origin polyphenol compounds (33). Herbs, due to the high content of phenol compounds, are able to neutralize free radicals (8). The evaluation of total polyphenol content in plant extracts, instead of extracting separate compounds, is justified in the case of the common use of herbal infusions, as in complex mixtures some of the ingredients may act synergistically and enhance the biological activity of other particular compounds.

We observed a diverse level of total polyphenol content in the tested herb species (Table 1). The highest mean levels were observed in $H$. perforatum (36.92 mg TAE/100 g DW), and the lowest in $S$. marianum (3.08 mg TAE/100 g DW). Different proportions between total polyphenol content in these species were observed by Wojdyło et al. (6) and could have resulted from the use of $80 \%$ methanol solution in the extraction, as the method of extraction clearly affects the further evaluation of polyphenol content in the plants. This statement is confirmed by studies in Macedonia where in $M . x$ piperita exhibited a more than 2 times higher content of total polyphenols in the methanol extracts compared to the water extracts (34). The content of polyphenols in water herbal extracts is, however, the real amount of these compounds that is provided to an organism with the herbal infusions.

Diverse total polyphenol contents were found not only between the species but also within them and between the regions of sample collection (Fig. 2). An exception is $C$. officinalis, where the measured values did not differ significantly between the samples collected in Podlasie and Ukraine. In $H$. perforatum, the most polyphenols were found in the samples from Pomerania, with 3 to 5 times higher levels than in the plants from Ukraine and Podlasie. In the same species from Macedonia and northern and north-western Serbia, a diverse content of polyphenols was also noted (35). Moreover, the level of polyphenol compounds in $M$. x piperita from Podlasie was 2 to 4 times higher in comparison to the herbs from Pomerania and Ukraine. Between the examined plants, a much lower concentration of polyphenols, irrespective of the region of sample origin, was observed in the seeds of S. marianum. We also noted a highly diverse levels of these compounds in these seeds, where from Podlasie they contained 5.5 times more polyphenols than those collected in Ukraine.

The content of particular polyphenol substances, their chemical composition, and antioxidative features, strongly depends on the species of plant, the place of its growth and physiological status $(6,8,36)$.

All the tested plant species were able to deactivate ABTS radicals and to reduce $\mathrm{Fe}^{3+}$ to $\mathrm{Fe}^{2+}$ (Table 1). The highest ABTS activity in the examined plants was found in water extracts of $H$. perforatum, which was 1.5 times higher than in $M$. x piperita, almost 4 times higher than in $C$. officinalis and even 33 times higher in comparison to S. marianum. Similar dependencies were observed in FRAP activity, and the difference between the two extremal species in the row (H. perforatum and S. marianum) was about 47 times. In our study, also a diversified level of ABTS (Fig. 2) and FRAP (Fig. 3) activity was observed in plants from the same species but collected in different locations. The highest diversification within a species was observed in $H$. perforatum and $M$. x piperita, and the highest potential to neutralize free radicals (ABTS) and ferric reducing ability of plasma (FRAP) was typical for $H$. perforatum from Pomerania and $M$. x piperita from Podlasie. A diverse antioxidative activity in $H$. perforatum was also noted in plants from Macedonia and northern and north-western Serbia (35). Our analyzes of $S$. marianum seeds were contrary to the results of Pendry et al. (37), where we found a very low antioxidant activity, irrespective of the site of harvest. This situation may probably result from the method of extraction, as in the case of earlier measurements of polyphenol content. Wojcikowski et al. (38) showed in S. marianum a close relationship 
between the type of diluent used in the extraction and the antioxidative activity.

Data shown in Table 1 and Figures 2-4 show that the extracts characterized by a higher content of total polyphenols also represent higher levels of antioxidative activity. Usually, the dependencies between the content of polyphenols and antioxidative potential are statistically significant and are characterized by high values of coefficients of correlations (36). This indicates the important role of polyphenols as an antioxidative substance in plants. The results of our experiments also indicate this relationship in two species (Table 2). A significant and almost complete Pearson rank correlation was noted between total polyphenol content and ABTS and FRAP activity in $H$. perforatum $(\mathrm{R}=0.901$, $\mathrm{p} \leq 0.001, \mathrm{R}=0.998, \mathrm{p} \leq 0.01$, respectively) and in $M$. $x$ piperita $(\mathrm{R}=0.939, \mathrm{p} \leq 0.001, \mathrm{R}=0.986$, $\mathrm{p} \leq 0.01$, respectively). Some linear dependencies between the antioxidative activity and total polyphenol content have already been found for Hypericum genus plants collected in Turkey (39), in Poland $M$. $x$ piperita (40) and Romania C. officinalis (41). The results of our studies do not confirm this dependency in the case of $C$. officinalis, however our data clearly indicates the presence of a significant and very high or almost complete Pearson rank correlation between Se content and ABTS and FRAP potential $(\mathrm{R}=0.824, \mathrm{p} \leq 0.001, \mathrm{R}=0.977, \mathrm{p} \leq 0.01$, respectively), similar to $H$. perforatum $(\mathrm{R}=0.892$, $\mathrm{R}=0.832, \mathrm{p} \leq 0.01$, respectively). This means that there is a clear dependency between the observed selenium content and antioxidative potential in these two species. Moreover, in C. officinalis a close relationship between the content of $\mathrm{Se}$ and total polyphenols $(\mathrm{R}=0.884, \mathrm{p} \leq 0.001)$ was observed. It has been shown that exogenic Se used in low concentrations stimulated the synthesis of polyphenol compounds in Lycopersicon esculentum (42).

\section{CONCLUSIONS}

Our study demonstrated differentiated levels of selenium in drought of plants, total polyphenols and antioxidative potential (ABTS and FRAP) in water extracts of plants within a separate species in reference to the region of sample collection. Herbs from Ukraine, excluding $H$. perforatum, were characterized by a higher selenium abundance in comparison to plants from Poland. The lowest level of Se diversification between the regions was observed in $C$. officinalis and $H$. perforatum. A highly significant positive correlation between the content of selenium and both ABTS and FRAP antioxidative potential in these two species indicates a significant share of Se in the antioxidative properties of these plants. In $C$. officinalis, a very high and significant correlation indicates a relationship between the level of selenium and polyphenol content.

The highest level of polyphenols and antioxidative properties, and the highest diversity in the levels of these elements in relation to the regions of sample collection was observed in $H$. perforatum (Pomerania) and M. x piperita (Podlasie). A very high positive correlation between total polyphenols and both ABTS and FRAP activity in $M$. x piperita and $H$. perforatum confirm the significant role of polyphenols in the antioxidative potential of these plants.

All the examined herb species may be considered as valuable sources of exogenic antioxidants, and as a Se supplement in the human diet.

\section{Acknowledgments}

We would like to thank Mr. Mirosław Angielczyk from "Ziołowy Zakątek" in Koryciny for sharing the research material used in this study. We are also grateful to the anonymous reviewers for their constructive comments that have allowed us to significantly improve on the first manuscript version.

\section{REFERENCES}

1. Berger M.M., Chiolero R.L.: Crit. Care Med. 35, 584 (2007).

2. Pala F.B., Gurkan H.: Adv. Mol. Biol. 1, 1 (2008).

3. Korotkova E.I., Misini B., Dorozhko E.V., Bukkel M.V., Plotnikov E.V., Linert W.: Int. J. Mol. Sci. 12, 401 (2011).

4. W.H.O. Trace Elements in Human Nutrition and Helth, pp. 34-89. World Helth Organization, Geneva 1996.

5. Tapiero H., Townsend D.M., Tew K.D.: Biomed. Pharmacother. 57, 134 (2003).

6. Wojdyło A., Oszmiański J., Czemerys R.: Food Chem. 105, 940 (2007).

7. Devi O.A., Das M., Saikia A., Das P., Sharma D.: J. Med. Plants Stud. 4, 189 (2016).

8. Katalinic V., Milos M., Jukic M.: Food Chem. 94, 550 (2006).

9. Mubashar Sabir S., Khan M.F., Rocha J.B.T., Boligon A.A., Athayde M.L.: J. Food Biochem. 39, 316 (2015).

10. Rigane G., Ben Younes S., Ghazghazi H., Ben Salem R.: IFRJ 20, 3001 (2013). 
11. Neukirch H., D’Ambrosio M., Via J.D. Guerriero A.: Phytochem. Anal. 15, 30 (2004).

12. Barnes J., Anderson L.A., Phillipson J.D.: J. Pharm. Pharmacol. 53, 583 (2001).

13. Derwich E., Chabir R., Taouil T., Senhaji O.: IJPSDR 3, 130 (2011).

14. Rainone F.: Am. Fam. Physician 72, 1285 (2005).

15. Gazak R., Walterova D., Kren V.: Curr. Med. Chem. 14, 315 (2007).

16. Raibhar K., Dawda H., Mukundan U.: Sci. Revs. Chem. Commun. 5, 1 (2015).

17. Peel M.C., Finlayson B.L., McMahon T.A.: Hydrol. Earth Syst. Sci. 11, 1633 (2007).

18. https://pl.climate-data.org.

19. Watkinson J.H.: Anal. Chem. 38, 92 (1966).

20. Grzebuła S., Witkowski P.: Pol. Arch. Weter. 20, 125 (1977).

21. Anastasiadi M., Pratsinis H., Kletsas D., Skaltsounis A.L., Haroutounian S.A.: Food Res. Int. 43, 805 (2010).

22. Shi F., Jia X., Zhao C., Chen Y.: Molecules 15, 4934 (2010).

23. Benzie I.F.F., Strain J.J.: Anal. Biochem. 239, 70 (1996).

24. Antal D.S., Canciu C.M., Dehelean C.A., Anke M.: An. Univ. Oradea Fasc. Biol. 17, 23 (2010).

25. Schrauzer G.N.: in Elements and their Compounds in the Environment, 2ed edn., Merian E., Anke E., Ihnat M., Stoepler M. Eds., pp. 1365-1406. Wiley VCH Verlag, Weinheim 2004.

26. Terry N., Zayed A., De Souza M.P., Tarun A.S.: Annu. Rev. Plant Physiol. Plant Mol. Biol. 51, 401 (2000).

27. Vogrincic M., Cuderman P., Kreft I., Stibilj V.: Anal. Sci. 25, 1357 (2009).
28. Geering H.R., Cary E.E., Jones L.H.P., Alloway W.H.: Soil Sci. Soc. Am. Pro. 32, 35 (1968).

29. Bitterli C., Bañuelos G.S., Schulin R.: J. Geochem. Explor. 107, 206 (2010).

30. Reimann C., Birke M., Demetriades A., Filzmoser P., O'Connor P.: Chemistry of Europe's agricultural soils. Geologisches Jahrbuch (Reihe B) 2013.

31. Pilarczyk B., Balicka-Ramisz A., Ramisz A., Vovk S., Krużel B., Tomza A.: Umschau 62, 123 (2007).

32. Borowska K., Koper J., Tykwińska T.: Ochr. Śr. Zasob. Nat. 31, 18 (2007).

33. Pham-Huy L.A., He H., Pham-Huy C.: Int. J. Biomed. Sci. 4, 89 (2008).

34. Mihajlov L., Veličkovska S.K.: Sixth International Scientific Agricultural Symposium “Agrosym 2015”. Jahorina 2015. 10.7251/AGS Y150051127M.

35. Božin B., Kladar N., Grujić N., Anačkov G., Samojlik I. et al.: Molecules 18, 11733 (2013).

36. Kofidis G., Bosabalidis A.: Biol. Lett. 49, 65 (2013).

37. Pendry B., Busia K., Bell C.M.: OPEM 6, 167 (2006).

38. Wojcikowski K., Stevenson L., Leach D., Wohlmuth H., Gobe G.: J. Altern. Complem. Med. 13, 103 (2007).

39. Öztürk N., Tunçel M., Potoglu-Erkara I.: Pharm. Biol. 47, 120 (2009).

40. Czapecka E., Mareczek A., Leja M.: Food Chem. 93, 223 (2005).

41. Butnariu M., Coradini C.Z.: Chem. Cent. J. 6, 35 (2012).

42. Schiavon M., dall'Acqua S., Mietto A., PilonSmits E.A.H., Sambo P. et al.: J. Agric. Food Chem. 61, 10542 (2013).

Received: 14.08. 2017 